\title{
Phytochemical Analysis and Toxicity Evaluation of Acetone, Aqueous and Methanolic Leaf Extracts of Agapanthus praecox Willd
}

\author{
Sharaibi OJ and Afolayan $\mathrm{AJ}^{*}$ \\ Department of Botany, University of Fort Hare, South Africa
}

Submission: August 08, 2018; Published: August 29, 2018

*Corresponding author: Anthony J Afolayan, Department of Botany, Medicinal Plants and Economic Development Research Centre, University of Fort Hare, Alice, South Africa; Email: aafolayan@ufh.ac.za

\begin{abstract}
Agapanthus praecox Willd of the family Amaryllidaceae is widely used in South African traditional medicine to treat heart disease, paralysis, coughs, colds, chest pains and diarrhea. The decoction is used to prevent pregnancy complications and argument labor. The study aims at determining the phytochemical constituents and investigating the potential toxicity of the solvent extracts of $A$. praecox. Quantitative phytochemical analysis was done using standard procedures and spectrophotometric techniques while the toxicity assessment was carried out with brine shrimp toxicity bioassay. The data were subjected to two-way analysis of variance (ANOVA) followed by Tukey's test. Methanol had the highest percentage yield of extract (16.2 \%) while water (9.3\%) was the least. The quantities of tannins $\left(335.23 \mathrm{mg}^{-1} \mathrm{~g}^{-1}\right)$, phenols $\left(91.11 \mathrm{mg} \mathrm{g}^{-1}\right)$, proanthocyanidins $\left(139.47 \mathrm{mg} / \mathrm{g}^{-1}\right)$, flavonoids $\left(46.53 \mathrm{mg} / \mathrm{g}^{-1}\right)$ and flavanols $\left(74.02 \mathrm{mg} / \mathrm{g}^{-1}\right)$ in acetone extract were significantly higher $(\mathrm{p}>0.05)$ than in aqueous and methanolic extracts. Highest hatching success was recorded in aqueous extract (50.33\%) and the lowest hatching success $(\mathrm{p}<0.05)$ was recorded in the positive control (amoxicillin). The $\mathrm{LC}_{50}$ of all the solvent extracts was greater than $1 \mathrm{mg} / \mathrm{mL}\left(\mathrm{LC}{ }_{50}>1 \mathrm{mg} / \mathrm{mL}\right)$ while the positive control (amoxicillin) had a lesser $\mathrm{LC}_{50}(0.76 \mathrm{mg} / \mathrm{mL})$. Organic solvents of fresh leaves of A. praecox contained significant phytochemicals that were not toxic according to Meyer's index of toxicity, which states that any substance with $\mathrm{LC}_{50}>1 \mathrm{mg} / \mathrm{mL}$ were considered non-toxic. Further toxicological evaluation assays are recommended to confirm the toxicity of A. praecox.
\end{abstract}

Keywords: Agapanthus praecox; Plant extracts; Phytochemicals; Toxicity; Brine shrimp; Hatchability; Lethality

\section{Introduction}

The ever-increasing interest in the use of medicinal plants to treat different ailments and diseases necessitates the investigation of their potential toxicities. Most people in developing countries rely on medicinal plants for their primary health care. Diversity, flexibility, easy accessibility, relative low cost, low levels of technological input and relative low side effects are some of the positive features of traditional medicine [1]. All medicinal plants contain active principles such as saponins, tannins, alkaloids, phenols, flavonoids, anthocyanins, glycosides etc. which are responsible for their biological activities [2]. These active principles have been reported to possess therapeutic as well as toxicological properties [3]. The toxicity of the medicinal plants has been attributed to the quantities and strength of their active principles [4]. As the global interest in the use of medicinal plants is increasing, public health issues and concerns surrounding their safety are also increasingly recognized. The ethno pharmacological significance of Agapanthus praecox in South African folkloric medicine made it suitable for the current study.

Agapanthus praecox locally called "Isicakathi" (Isixhosa) is a rhizomatous herb of the family Amaryllidaceae. This species occurs in Eastern Cape Province of South Africa. It usually grows to between 0.8 and 1 metre tall and has 10-11 leathery leaves. The blue to purple or white flowers are clustered in a large globular flower head. The fruit is a greenish capsule. It possesses anti-inflammatory, anti-oedema, antitussive, immunoregulatory, antibacterial, antifungal, and antitumour properties [5]. It is used in folkloric medicine to treat chest pains, coughs and colds [6]. Duncan et al. reported its inhibition of angiotensin converting enzyme in vitro hence, used to treat high blood pressure and related disorders [7]. The leaves with Dianthus sp. are used to treat gastrointestinal tract trouble and abdominal pains [8]. The leaves are used to hold dressings in place and wound around wrists to bring down fevers [9]. Koduru et al. also reported the anticancer potential of the root infusion [10].

Agapanthus praecox has been considered a plant of fertility and pregnancy; it has aphrodisiac property and is used as a medicine for impotency and barrenness [5]. It has been reported that the decoction can induce labour and ensure smooth expulsion of the placenta [11-12]. Pooley stated that "bathing the new born baby with the decoction of $A$. praecox makes them strong, keep them free from bowel problems and prevents crusts on the head" [13]. The anti- depressant property was reported by Nielsen et 
al. [14]. It was listed among the plant species traditionally used in Southern Africa for the treatment of various central nervous system-related ailments [15]. Despite, the wide usage of A. praecox in indigenous medicine system, its phytochemical constituents and potential toxicity remain unknown. Though, Notten [6] suspected its haemolytic poisoning in humans but this has not been proven. To furnish the general public including the traditional medicine practitioners with adequate information to facilitate better understanding of the risks associated with the use of this plant; this study aims at estimating the phytochemical constituents as well as evaluating the potential toxicity of Agapanthus praecox using brine shrimp toxicity testing as a preliminary test to ascertain its level of toxicity.

\section{Materials and Methods}

\section{Plant collection}

Fresh leaves of Agapanthus praecox were collected from the University of Fort Hare, Alice Campus, South Africa in June 2016. The plant was identified by Dr. OJ Sharaibi and a voucher specimen (SHAMed 2016/07) was deposited in the Giffen's herbarium of the University.

\section{Sample preparation and extraction}

The fresh leaves were rinsed, air dried and pulverized before extraction. One hundred gram each of the powdered materials was soaked in $1000 \mathrm{~mL}$ of distilled water, acetone and methanol respectively. The aqueous extract was filtered through Whatman no.1 paper and the filtrate was freeze-dried for $48 \mathrm{~h}$ using a freeze dryer (Vir Tis benchtop K, Vir Tis Co., Gardiner, NY). The acetone and methanolic extracts were concentrated to dryness under reduced pressure at $40^{\circ} \mathrm{C}$ using a rotary evaporator (Strike 202 Steroglass, Italy). The resulting extracts were reconstituted in their respective solvents to give the desired concentrations used in the study.

\section{Phytochemical Analysis}

\section{Determination of total phenol contents}

A volume of $0.5 \mathrm{~mL}$ of the extract $(1 \mathrm{mg} / \mathrm{mL})$ was mixed with $5 \mathrm{~mL}$ Folin-Ciocalteu reagent (previously diluted with water 1:9v/v) and $4 \mathrm{~mL}(75 \mathrm{~g} / \mathrm{L})$ of sodium carbonate. The tubes were vortexed for $15 \mathrm{~s}$ and allowed to stand for $30 \mathrm{~min}$ at $40{ }^{\circ} \mathrm{C}$ Absorbance was measured at $765 \mathrm{~nm}$ using AJI-C03 UV-VIS spectrophotometer. The results were expressed as $\mathrm{mg} / \mathrm{g}$ tannic acid equivalent using the equation based on the calibration curve:

$$
Y=0.1216 x, R=0.9365
$$

Where $x$ is the absorbance and $Y$ was the tannic acid equivalent

\section{Determination of flavonoids contents}

A volume of $0.5 \mathrm{~mL}$ of $2 \% \mathrm{AlCl}_{3}$ ethanol solution was added to $0.5 \mathrm{~mL}$ of the sample solution. After $1 \mathrm{~h}$ at room temperature, the absorbance was measured at $420 \mathrm{~nm}$. Extract samples were evaluated at a final concentration of $0.1 \mathrm{mg} / \mathrm{mL}$. The results were calculated as quercetin equivalent $(\mathrm{mg} / \mathrm{g})$ using the equation based on the calibration curve: $Y=0.0255 x, R^{2}=0.981$
Where $x$ was the absorbance and $Y$ was the quercetin equivalent

\section{Determination of total flavanols contents}

The reacting mixture of $2 \mathrm{~mL}$ each of the extracts with $2 \mathrm{~mL}$ of $\mathrm{AlCl}_{3}$ in ethanol solution and $3 \mathrm{~mL}$ of $50 \mathrm{~g} / \mathrm{L}$ sodium acetate solution was allowed to stay for $2.5 \mathrm{~h}$ at $20^{\circ} \mathrm{C}$ in a water bath. The absorbance was measured at $440 \mathrm{~nm}$. The flavanols contents were calculated thus: $Y=0.0255 x, R^{2}=0.9812$

where $x$ was the absorbance and $Y$ is the quercetin equivalent in $\mathrm{mg} / \mathrm{g}$.

\section{Determination of proanthocyanidins contents}

A volume of $0.5 \mathrm{~mL}$ each of the plant extracts was added to $3 \mathrm{~mL}$ of vanillin- methanol $(4 \% \mathrm{v} / \mathrm{v}) .1 .5 \mathrm{~mL}$ of hydrochloric acid was added to the reacting mixture and vortexed. The mixture was allowed to stand for $15 \mathrm{~min}$ at room temperature. Absorbance was measured at $500 \mathrm{~nm}$. Proanthocyanidins content was expressed as:

$$
Y=0.5825 x, R^{2}=0.9277
$$

where $x$ was the absorbance and $Y$ was the cathecin equivalent in $\mathrm{mg} / \mathrm{g}$.

\section{Determination of tannin contents}

The extracts weighing $0.20 \mathrm{~g}$ was added to $20 \mathrm{~mL}$ of $50 \%$ methanol, vortexed vigorously and later incubated at $80{ }^{\circ} \mathrm{C}$ in a water bath for $1 \mathrm{~h}$. The filtrate was mixed with $20 \mathrm{~mL}$ of distilled water, $2.5 \mathrm{~mL}$ of Folin-Dennis reagent and $10 \mathrm{~mL}$ of $17 \%$ aqueous $\mathrm{Na}_{2} \mathrm{CO}_{3}$. The mixture was made up to $100 \mathrm{~mL}$ with distilled water, mixed and allowed to stand for $20 \mathrm{~min}$. The absorbance of the tannic acid standard solutions and the sample was measured at $706 \mathrm{~nm}$. Results were expressed as $\mathrm{mg} / \mathrm{g}$ of tannic acid equivalent using the calibration curve:

$$
Y=0.0763 x, R^{2}=0.9644
$$

where $x$ was the absorbance and $Y$ was the tannic acid equivalent

\section{Determination of alkaloids contents}

A volume of $200 \mathrm{~mL}$ of $10 \%$ acetic acid prepared in ethanol was added to $5 \mathrm{~g}$ each of the extracts. This was covered and allowed to stand for $4 \mathrm{~h}$. The mixture was filtered and the filtrate was concentrated to one-fourth of the original volume in a water bath. Concentrated ammonium hydroxide was added drop-wisely to the extract, pending the completion of the precipitation. The solution was allowed to settle and re-filtered after washing with dilute ammonium hydroxide. The residue obtained was dried, weighed and the percentage composition was determined using the formula:

$\%$ Alkaloid= Final weight of the sample / Initial weight of the extract $\mathrm{x} 100$

\section{Determination of saponins content}

The extracts weighing $20 \mathrm{~g}$ was added to $100 \mathrm{~mL}$ of $20 \%$ aqueous ethanol and kept in a shaker for $30 \mathrm{~min}$. The mixture 
was heated over the water bath for $4 \mathrm{~h}$ at $55^{\circ} \mathrm{C}$ and then filtered to collect the residue which was later re-extracted with $200 \mathrm{~mL}$ of $2 \%$ aqueous ethanol. The filtrate was concentrated over the water bath at $90{ }^{\circ} \mathrm{C}$ to approximately $40 \mathrm{~mL}$. The concentrate was transferred into a $250 \mathrm{~mL}$ separatory funnel and extracted twice with $20 \mathrm{~mL}$ diethyl ether. The ether layer was discarded while the aqueous layer was retained and to which $60 \mathrm{ml} n$ - butanol was added. The mixture was washed twice with $10 \mathrm{~mL}$ of $5 \%$ aqueous sodium chloride. After evaporation, the samples were dried in the oven at $40{ }^{\circ} \mathrm{C}$ to a constant weight. The saponins content was calculated using the formula:

$\%$ Saponins= Final weight of residue/ Initial weight of the sample $x 100$.

\section{Brine Shrimp Toxicity Bioassay}

\section{Preparation of the assay system}

The assay system was prepared according to Ohikhena, et al. [16]. Five Petri dishes containing $30 \mathrm{ml}$ of the plant extracts dissolved in filtered seawater were prepared in a two-fold dilution to yield a series of concentrations $(1,0.5,0.25,0.125$ and $0.0625 \mathrm{mg} / \mathrm{mL}$ ) of the plant extracts. Amoxicillin dissolved in seawater $(30 \mu \mathrm{l} / \mathrm{ml})$ served as a positive control while Petri dishes containing sea water served as the negative controls. The experimental setup was allowed to stand in open air for $30 \mathrm{~min}$ for the solvents to evaporate.

\section{Brine shrimp hatchability assay}

Artemia salina (Brine shrimp) cysts were stocked at a density of 10 individuals per Petri dish. Each Petri dish contained $30 \mathrm{ml}$ of the incubation medium at varying concentrations $(1,0.5,0.25$, 0.125 and $0.0625 \mathrm{mg} / \mathrm{mL}$ ). They were partly covered, incubated at $28{ }^{\circ} \mathrm{C}$ and allowed to stand for $72 \mathrm{~h}$ under constant illumination. The number of free nauplii in each Petri dish was counted after every $12 \mathrm{~h}$. The percentage of hatchability was assessed by comparing the number of hatched nauplii with the total number of cysts stocked. The minimum inhibitory concentration (MIC) was determined as the minimum concentration of the plant extracts (or control drug) that inhibited hatching of the cysts.

\section{Brine shrimp lethality assay}

The lethality of $A$. praecox extracts against brine shrimp nauplii was evaluated by pipetting an aliquot $(0.1 \mathrm{ml})$ containing 10 nauplii into each Petri dish of extract solutions and controls. The setup was allowed to remain for $72 \mathrm{~h}$ under constant illumination; dead larvae in each Petri dish were counted after every $12 \mathrm{~h}$.

The percentage mortality (M \%) was calculated as:

$$
\operatorname{Mortality}(\%)=\frac{\text { Total nauplii- Alive nauplii } \times 100}{\text { Total nauplii }}
$$

\section{Statistical analysis}

Statistical analysis was performed using GraphPad Prism 5 statistical package (GraphPad Software, San Diego MA, USA). The data were subjected to one-way analysis of variance (ANOVA) followed by Tukey test. All the results were expressed as mean \pm
SEM $(n=3)$ and were considered statistically significant when $p$ $<0.05$.

\section{Results and Discussion}

\section{Dry extract yield}

Each $100 \mathrm{~g}$ of powdered leaves of $A$. praecox extracted in water, acetone and methanol yielded 9.3g, 11.6g and 16.2g of dry extract respectively. Methanol extracted more phytochemicals (16.2g) than water and acetone. The high dry extract yield recorded in methanol extract (16.2\%) may be due to high polarity of methanol which can draw high variety of plant constituents than the other solvents. This result agreed with some reports in the literatures. Anokwuru, et al. [17] reported higher yields of Acalypha wilkesiana, Azadirachta indica and Solanum scabrum in methanol extraction than in acetone. Also, Dhawan and Gupta [18] observed the highest extract yields in methanol solvent for all the plants studied.

\section{Phytochemical constituents}

The quantities of tannins $\left(335.2 \mathrm{mg} / \mathrm{g}^{-1}\right)$, phenols $(91.1 \mathrm{mg} / \mathrm{g}$ $\left.{ }^{1}\right)$, proanthocyanidins $\left(139.5 \mathrm{mg} / \mathrm{g}^{-1}\right)$, flavonoids $\left(46.5 \mathrm{mg} / \mathrm{g}^{-1}\right)$ and flavanols $\left(74.0 . \mathrm{mg} / \mathrm{g}^{-1}\right)$ in acetone extract were significantly higher $(p>0.05)$ than in aqueous and methanolic extracts. The amount of saponins in all the extracts was considerably while all the extracts contained little amounts of alkaloids. (Table 1).

Table 1: Phytochemicals of aqueous, acetone and methanolic leaf extracts of $A$. praecox.

\begin{tabular}{|c|c|c|c|}
\hline Phytochemicals & Aqueous & Acetone & Methanol \\
\hline Proanthocyanidins & 22.368 & 139.47 & 137.0428 \\
\hline Phenols & 48.3725 & 91.1149 & 74.0422 \\
\hline Flavonoids & 14.56 & 46.5299 & 10.4805 \\
\hline Flavanols & 20.6627 & 74.0148 & 35.5419 \\
\hline Tannins & 302.2396 & 335.4071 & 321.2306 \\
\hline Saponins & 123.0764 & 142.0865 & 132.0743 \\
\hline Alkaloids & 0.2961 & 0.4532 & 0.3562 \\
\hline
\end{tabular}

Values are the mean of the three replicates $(n=3)$.

The extracts of $A$. praecox contained a considerable amount of phytochemicals that have significant therapeutic and exhibit biological activities in humans. The presence of these phytochemicals may be responsible for the diverse uses of this plant in traditional medicine. The amount of tannins, phenols and proanthocyanidins in all the extracts were considerably high. According to Ben Mohamed et al. [19], polyphenols levels are considerably affected by genetic factors like plant species, plant organ, phenological stage, and environmental factors like climatic conditions, biotic and abiotic stresses occurring during plant growth. Basma, et al. [20] and Chew, et al. [21] also identified higher amounts of polyphenols in leaves than the remaining plant organs. The phenolics have been reported to have antimicrobial, anti-inflammatory and antioxidant activities [22]. Proanthocyanidins have a putative role as antioxidants, they affect the inflammatory process and protect against $\mathrm{H}_{2} \mathrm{O}_{2}$-induced lipid peroxidation [23]. Yamakoshi, et al. [24] investigated the toxicity 
of proanthocyanidins from grape seed extracts and reported lack of toxicity in both acute and sub-acute toxicity studies and supported the use of proanthocyanidins as food supplements. The quantities of saponins in A. praecox leaves in all the extracts were very high; acetone extract (142\%), methanolic extract (132\%) and aqueous extract (123\%). Ezeabara, et al. [25] also reported higher levels of saponins in the leaves of Citrus sinensis and peel of Citrus aurantifolia. Liu and Henkel [26] considered saponins and polyphenols as key ingredients in traditional Chinese medicines which are responsible for most of the observed biological activities. The saponins in A praecox leaves may also possess anti-inflammatory and antibacterial activity which may justify its usage in the traditional medicine for the treatment of wounds. The amount of alkaloids in the leaves of $A$. praecox was very small $(0.296 \%)$. The alkaloids present in the leaves of $A$. praecox may be responsible for its antimicrobial activity reported in the literatures; since it plays role in the defence of systems against pathogens [27].

\section{Brine shrimp hatchability assay}

The percentage hatching success of $A$. salina in different solvent extracts and the controls were represented in (Figure 1a $\& 1 b)$.

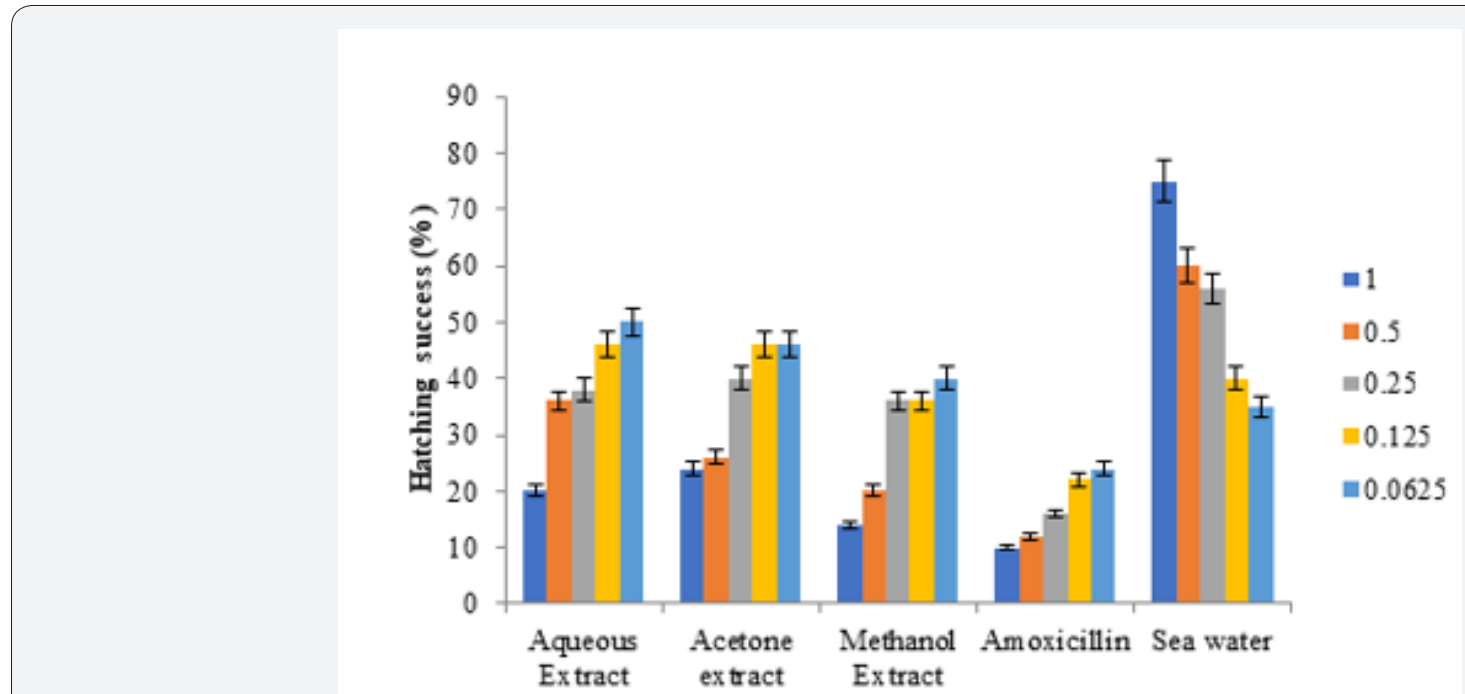

Figure 1a: Percentage hatchability of $A$. salina cysts in different concentrations of extracts of Agapanthus praecox, amoxicillin and sea water.

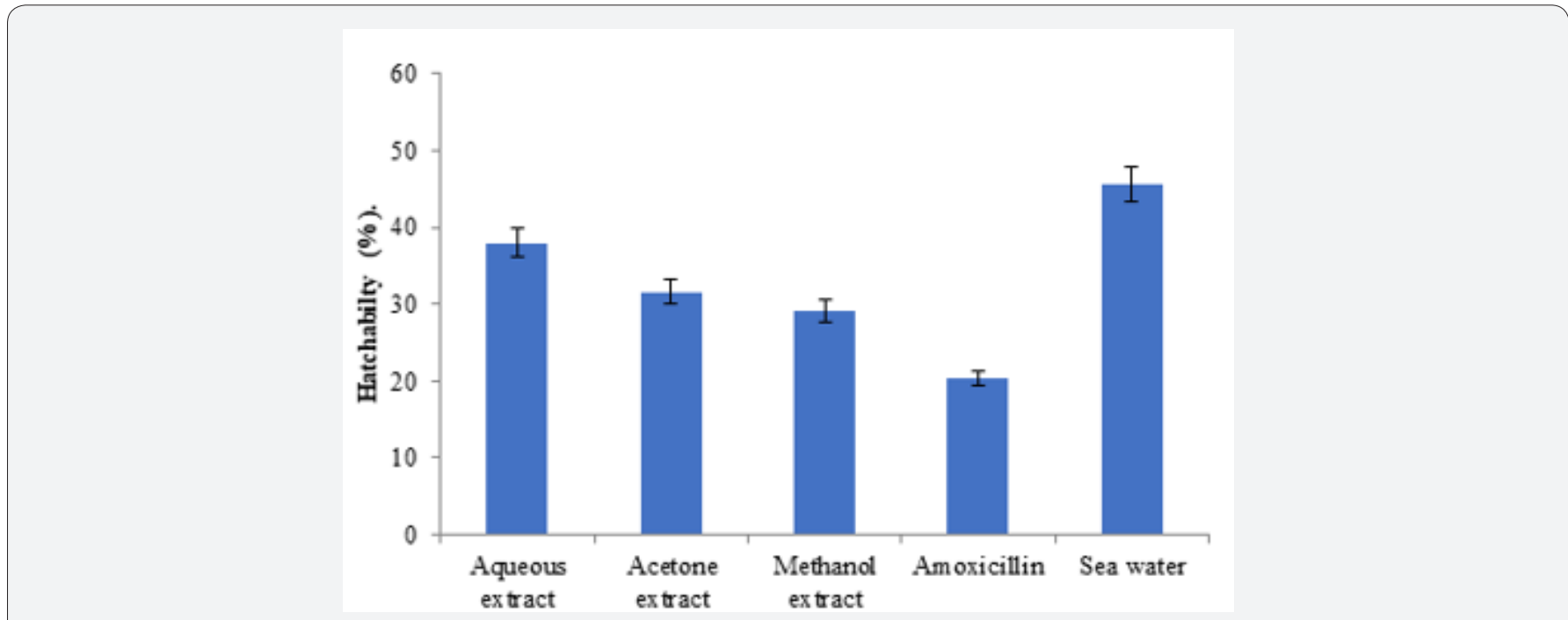

Figure 1b: Percentage hatchability of $A$. salina cysts in different extracts of Agapanthus praecox, amoxicillin and sea water.

Highest hatching success was recorded in the aqueous extract (50.33\%) compared with methanol extract (40.45\%) and acetone extract (40.35\%). The positive control, amoxicillin produced the least hatching success (24\%). The order of percentage hatchability of $A$. salina cysts was aqueous extract $>$ methanol extract $>$ acetone extract> amoxicillin. This suggested that aqueous extract had low inhibitory activity against the A. salina cysts and this may justify the use of water in herbal preparations. Similar hatching success recorded in acetone extract $(40.35 \%)$ and methanolic extract $(40.45 \%)$ may be due to the strength and the quantity of 
the phytochemicals present in these extracts. According to Tulay [3], the toxicity of the medicinal plants can be attributed to the strength and quantity of their secondary metabolites.

The hatchability increased with decrease in concentrations of all the solvent extracts with highest hatching success observed in $0.0625 \mathrm{mg} / \mathrm{mL}$. This may be due to tolerance of $A$. salina being at resistant cyst stage to a wide range of salinity and until the dormancy is broken, hatching will not occur. It may also mean that all the extracts at $1 \mathrm{mg} / \mathrm{mL}$ had inhibitory effects and therefore prevented the cysts from hatching. The increase in the rate of hatchability with time suggests the nutritive potential of the extract that the cysts thrived on as incubation progresses. The highest hatching rate of the cysts for all the extracts was observed after $72 \mathrm{~h}$ of incubation. This contradicted Ohikhena et al. [16], who reported highest hatching success after $36 \mathrm{~h}$ of incubation in various solvent extracts of Phragmanthera capitata. The difference in significant hatching time may be due to difference in plant species as reported by Tulay [3].

\section{Brine shrimp lethality assay}

The results of the percentage lethality of $A$. salina cysts in different solvent extracts of Agapanthus praecox, amoxicillin and sea water were shown in (Figures 2a \& 2b).

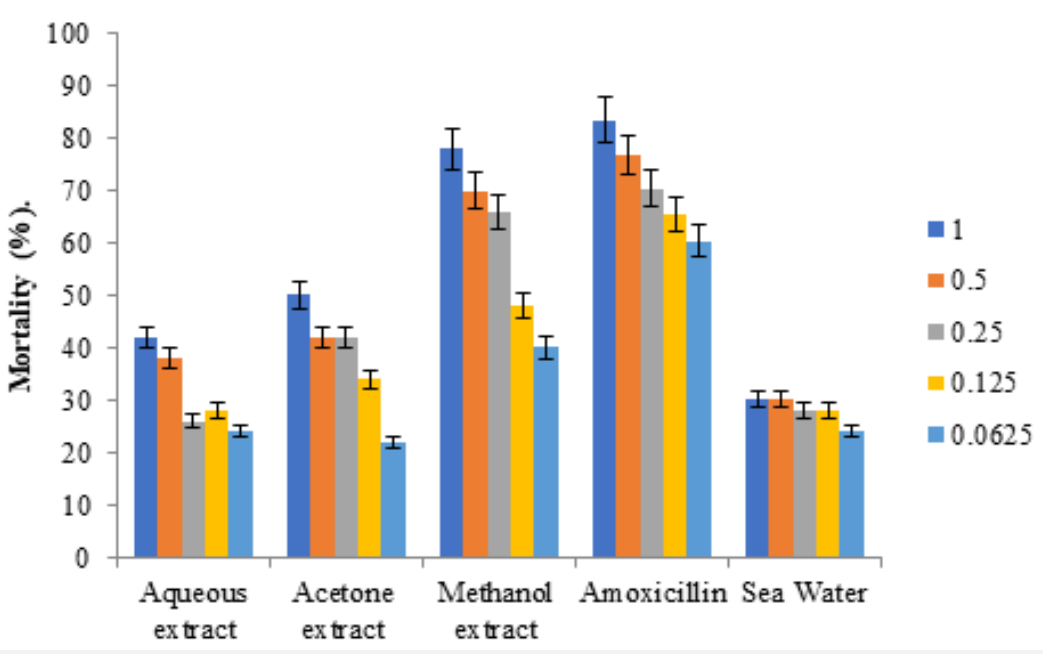

Figure 2a: Percentage lethality of $A$. salina in different concentrations of extracts of $A$. praecox, amoxicillin and sea water.

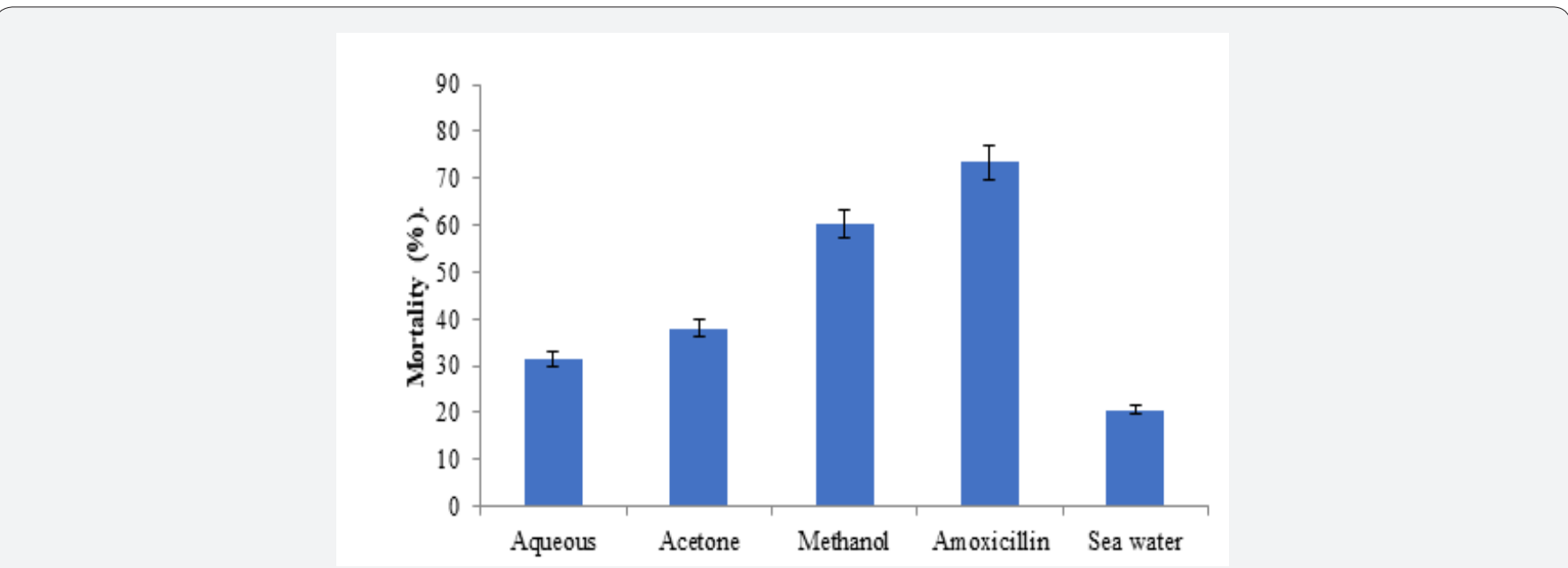

Figure 2b: Percentage lethality of $A$. salina in different concentrations of extracts of $A$. praecox, amoxicillin and sea water.

Among the extracts studied, the highest percentage lethality was observed in methanol extract (78.53\%) compared with acetone extract (50.22\%) and aqueous extract (42.35\%). Ogugu, et al. [28] stated that the type of solvent for the extraction process is vital for the toxicity testing, because different solvents show different extracting potential. The highest mortality rate observed in methanol extract can be due to the quantity and the type of phytochemicals present in the extract; since, methanol had the highest yield of extract during the extraction process of this study.

The highest mortality rate of $A$. salina cysts was observed in $1 \mathrm{mg} / \mathrm{mL}$ of all the solvent extracts tested. This means increase in concentration increased the mortality rate and that the $\mathrm{LC}_{50}$ of all 
the extracts studied were greater than one $(>1)$, hence the extracts were not toxic. According to Meyer's toxicity index, extracts with $\mathrm{LC}_{50}<1000 \mu \mathrm{g} / \mathrm{ml}$ are considered as toxic, while extracts with $\mathrm{LC}_{50}$ $>1000 \mu \mathrm{g} / \mathrm{ml}$ are considered as non-toxic [29].

The rate of mortality increased with increase in time hence, the highest mortality rate was observed after $72 \mathrm{~h}$ of incubation of $A$. salina cysts in all the extracts. The longer the nauplii were exposed to the plant extracts, the higher the mortality. Significant mortality observed in all the plant extracts after $72 \mathrm{~h}$ of incubation suggests that the plant extracts have some nutrients on which the nauplii fed on and that the toxic effects of the plant extracts on the nauplii were delayed but later manifested after a long time of exposure. This agreed with the reports of Ohikhena et al. [16] and Otang et al. [30]. According to Ahmed, et al. [31], the toxicity of plant samples was determined by comparing their $\mathrm{LC}_{50}$ values with highly toxic substances suitable to be used as positive controls for this test. In Figure $2 \mathrm{~b}$, amoxicillin had the highest percentage lethality (78.05\%) in $1 \mathrm{mg} / \mathrm{mL}$ than all the plant extracts and this showed that amoxicillin used as positive control in this study was more toxic than all the plant extracts (Table 2).

Table 2: Hatchability and Lethality of Artemia salina cysts in different solvent extracts of Agapanthus praecox and positive control as shown by their $\mathrm{MIC}_{50}$ and $\mathrm{LC}_{50}$ values.

\begin{tabular}{|c|c|c|}
\hline Extract & MIC50 $(\mathbf{m g} / \mathbf{m l})$ & $\mathbf{L C}_{\mathbf{5 0}}(\mathbf{m g} / \mathbf{m l})$ \\
\hline Acetone extract & 0.16 & $>1$ \\
\hline Aqueous extract & 0.62 & $>1$ \\
\hline Methanol extract & 0.12 & $>1$ \\
\hline Amoxicillin & $<0.0625$ & 0.76 \\
\hline
\end{tabular}

\section{Conclusion}

The different phytochemicals present in the leaf extracts of $A$. praecox are of significant biological activities; their presence may justify the diverse uses of $A$. praecox in South African traditional medicine. It was discovered from this study that, all the solvent extracts of Agapanthus praecox were not toxic $\left(\mathrm{LC}_{50}>1 \mathrm{mg} / \mathrm{mL}\right)$ in brine shrimp toxicity bioassay. It was confirmed from this study that water is the best solvent for preparation of A. praecox as it poses less risk to the users. Caution should be taken when using this plant and continuous use should be discouraged. Further investigation is necessary to determine the toxicity of the methanol extract of this plant as methanol extract exhibited the highest toxicity when compared with aqueous and acetone extracts.

\section{Acknowledgment}

The authors thank Govan Mbeki Research and Development Centre, University of Fort Hare, South Africa; for the financial support given to this study.

\section{Referencers}

1. Van Andel TR, Carvalheiro LG (2013) Why urban citizens in developing countries use traditional medicines: the case of Suriname. Evidence Based Complementary and Alternative Medicine, Article ID: 687197.

2. Afolayan AJ, Sharaibi OJ, Kazeem MI (2013) Phytochemical Analysis and In vitro Antioxidant Activity of Nymphaea lotus L. International Journal of Pharmacology 9(5): 297-304.
3. Tülay AC (2012) Potential Genotoxic and Cytotoxic Effects of Plant Extracts. A Compendium of Essays on Alternative Therapy. Edited by Arup Bhattacharya Publisher.

4. Nasri H, Shirzad H (2013) Toxicity and safety of medicinal plants. Journal of Herb Med Pharmacology 2(2): 21-22.

5. Van Wyk BE, Oudtshoorn B, Gericke N (2000) A Text Book of Medicinal Plants of South Africa. Briza Publications, Second Edition 2000.

6. Notten A (2004) Agapanthus praecox Willd. South African National Biodiversity Institute, South Africa.

7. Duncan AC, Jäger AK, Staden J (1999) Screening of Zulu medicinal plants for Angiostensin converting enzyme (ACE) inhibitors. Journal of Ethnopharmacology 68(1-3): 63-70.

8. Duncan G (2002) A Text Book of Grow Agapanthus: A guide to the species, cultivation and propagation of the genus Agapanthus. Trident Press, South Africa.

9. Snoeijer W (2004) A Text Book of Agapanthus: a revision of the genus. Timber Publication, ( $4^{\text {th }}$ edn), USA.

10. Koduru S, Grierson DS, Afolayan AJ (2007) Ethnobotanical information of medicinal plants used for treatment of cancer in the Eastern Cape Province, South Africa. Current Science 92(7): 906-908.

11. Steenkamp V (2003) Traditional herbal remedies used by South African women for gynaeacological complaints. J Ethnopharmacol 86(1): 97-108.

12. Kaido TL, Veale DJH, Havlik I, Rama DBK (1997) Preliminary screening of plants used in South Africa as traditional herbal remedies during pregnancy and labour. J Ethnopharmacol 55(3): 185-191.

13. Pooley E (2003) A Text Book of Mountain flowers. A field guide to the flora of the Drakensberg and Lesotho. The Flora Publications Trust.

14. Nielsen ND, Sandager M, Stafford GI, van Staden J, Jäger AK (2004) Screening of indigenous plants from South Africa for affinity to the serotonin reuptake transport protein. J Ethnopharmacol 94(1): 159163.

15. Stafford GI, Jäger AK, van Staden J (2005) Activity of traditional South African sedative and potentially CNS-acting plants in the GABAbenzodiazepine receptor assay.J Ethnopharmacol 100(1-2):210-215.

16. Ohikhena FU, Wintola OA, Afolayan AJ (2016) Toxicity Assessment of Different Solvent Extracts of the Medicinal Plant, Phragmanthera capitata (sprengel) balle on brine shrimp (Artemia salina). International Journal of Pharmacology 12(7): 701-710.

17. Anokwuru CP, Ramaite DI, Bessong P (2015) Phenolic content distribution and antioxidant activities of Terminalia sericea burch. African Journal of Traditional Complementary and Alternative Medicine 12(4): 21-27.

18. Dhawan D, Gupta J (2017) Comparison of Different Solvents for Phytochemical Extraction Potential from Datura metel Plant Leaves. International Journal of Biological Chemistry 11(1): 17-22.

19. Ben Mohamed Maoulainine L, Jelassi A, Hassen I, Ould A, Ould B (2012) Antioxidant proprieties of methanolic and ethanolic extracts of Euphorbia helioscopia, (L.) aerial parts. International Food Research Journal 19(3): 1125-1130.

20. Basma AA, Zakaria Z, Latha LY, Sasidharan S (2011) Antioxidant activity and phytochemical screening of the methanol extracts of Euphorbia hirta L. Asian Pac J Trop Med 4(5): 386-390.

21. Chew YL, Chan EW, Tan PL, Lim YY, Stanslas J, et al. (2011) Assessment of phytochemical content, polyphenolic composition, antioxidant and antibacterial activities of Leguminosae medicinal plants in Peninsular Malaysia. BMC Complement Altern Med 11:12.

22. Amoo So, Ndhlala AR, Finnie JF, Van Staden J (2011) Antifungal acetylcholinesterase inhibition, antioxidant and phytochemical 
properties of three Barleria species. South African Journal of Botany $77(2): 435-445$.

23. Chen SC, Chung KT (2000) Mutagenicity and antimutagenicity of tannic acid and its related compounds. Food Chem Toxicol. 38(1): 1-5.

24. Yamakoshi J, Saito M, Kataoka S, Kikuchi M (2002) Safety evaluation of proanthocyanidin-rich extract from grape seeds. Food Chem Toxicol 40(5): 599-607.

25. Ezeabara CA, Okeke CU, Aziagba BO, Ilodibia CV, Emeka AN (2014) Determination of Saponin Content of Various Parts of Six Citrus species. International Research Journal of Pure \& Applied Chemistry 4(1): 137-143.

26. Liu J, Henkel T (2002) Traditional Chinese medicine (TCM): Are polyphenols and saponins the key ingredients triggering biological activities? Current Medicinal Chemistry 9(15): 1483-1485.

27. Patel K, Gadewar M, Tripath R, Prasad SK, Patel DK (2012) A review on medicinal importance, pharmacological activity and bioanalytical

This work is licensed under Creative

Commons Attribution 4.0 License

DOI: 10.19080/JCMAH.2018.07.555722 aspects of beta-carboline alkaloid Harmine. Asian Pacific Journal of Tropical Medicine 2: 660-664.

28. Ogugu SE, Kehinde AJ, James BI, Paul DK (2012) Assessment of cytotoxic effects of methanol extract of Calliandra portoricensis using Brine Shrimp (Artemia salina) Lethality Bioassay. Global Journal of BioScience and Biotechnology 2: 257-260.

29. Meyer BN, Ferrigni NR, Putnam JE, Jacobsen LB, Nichols DE, et al (1982) A Text Book of Brine Shrimp: A convenient general bioassay for active plant constituents. Planta Medica 45(5): 31-34.

30. Otang MW, Grierson SD, Ndip NR (2013) Assessment of potential toxicity of three South African Medicinal plants using brine shrimp (Artemia salina) assay. African Journal of Pharmacy and Pharmacology $7(20): 1272-1276$.

31. Ahmed Y, Sohrab H, Al-Reza SM, Shahidulla- Tareq F, Hasan CM, et al. (2010) Antimicrobial and cytotoxic constituents from leaves of Sapium baccatum. Food Chemistry and Toxicology 48(2): 549-552.

\section{Your next submission with Juniper Publishers} will reach you the below assets

- Quality Editorial service

- Swift Peer Review

- Reprints availability

- E-prints Service

- Manuscript Podcast for convenient understanding

- Global attainment for your research

- Manuscript accessibility in different formats (Pdf, E-pub, Full Text, Audio)

- Unceasing customer service

Track the below URL for one-step submission https://juniperpublishers.com/online-submission.php 